\title{
GENOTYPIC POTENTIALITY AND SELECTION INDEX OF RIDGE GOURD (LUFFA ACUTANGULA L.)
}

\author{
Ayasha Ahmed*, Jahangir Alam Tarafder, Mohammad \\ Kamal Hoassain and Nazmul Alam
}

Department of Botany, Jahangirnagar University, Savar, Dhaka-1342, Bangladesh

Keywords: Genotypic potentiality, Path analysis, Selection index, Ridge gourd

\begin{abstract}
Fifteen ridge gourd genotypes were investigated to select the superior genotypes. The overall analysis reveals that PCV was higher than GCV for all the traits. Significant variation was found among genotypes for the qualitative traits under divergence analysis. The selection index reveals that maximum genetic gain and relative efficiency over selection for yield was obtained for the index $\mathrm{I}_{123}$ based on yield/plant (g), No. of secondary branch, No. of male flower/plant characters. In the presented functions, selection index $\mathrm{I}_{1234}$ and $\mathrm{I}_{12345}$ showed highest relative efficiency over direct selection and genetic gain when all the characters were included to construct the selection index. On the basis of performance, the genotype-3023 was found to be most promising parent in order to develop a commercial ridge gourd variety.
\end{abstract}

Ridge gourd (Luffa acutangula L.) commonly known as Chinese okra, sponge gourd or even angled luffa, a tropical or sub-tropical vegetable is found in all parts of Bangladesh. At present production of ridge gourd in Bangladesh is about 50 thousand tons in one cropping season (BBS 2018). Sponge gourd is a highly nutritive vegetable and contains moisture, protein, fat, carbohydrate, vitamins, minerals of edible portion (Gopalan et al. 1999). The unripe fruit of ridge gourd is primarily used as a cooking vegetable in different regions of Bangladesh and other countries. Matured fibers are generally used in washing ships and decks and manufacturing slippers or baskets and used as shoe mats, inner cloth of bonnet (Lee and Yoo 2006). Sponge gourds are also used as absorbent (Altinisik et al. 2010). As an important summer vegetable ridge gourd becomes very popular among consumers for its variation in taste, shape and colour but very little research has been conducted in Bangladesh on the growth and development of ridge gourd variety. Lack of improved variety and frequent infestation pathogens are the main obstacles in ridge gourd production. Evaluation of genotypic potentiality in any crop is a breeders treasure for the entire crop improvement programme. There must be constant search traits for improving and establishing yield and other characters because an effective breeding programme aimed at yield of a crop. Correlation coefficients indicated an association among the characters (Shekhavat et al. 2005), also provide a measure of genotypic association between the characters and reveals the characters that might be useful as an index of selection. The path analysis facilitates the partitioning of correlation coefficients into the direct and indirect effects of component characters on yield and any other attributes. Therefore, present study was undertaken for evaluation of ridge gourd genotypes for selecting the superior one(s).

An experiment was conducted at the Botanical Garden of Jahangirnagar University, Savar, Dhaka during May to September, 2015 to evaluate performance of 15 ridge gourd genotypes using CRBD with two replications. The unit pits were 3 feet $\times 3$ feet with 1 feet spacing in row and 2 feet spacing as a drain in both side of the row. The observation was recorded on length of main vine, primary branches per plant, secondary branches per plant, days to first male flowering, days to first female flowering, no. of male flower/plant, number of female flower/plant, fruit length, fruit width, fruit pedicel length, number of seed/fruit, 100-seed weight, number of fruit/plant, fresh

*Author for correspondence: <ahmedayasha541@gmail.com>. 
weight/fruit and yield per plant. Raw data were used to calculate the correlation and path analysis by Indostat 9.1 software. Genotypic and phenotypic variance - covariance matrix with economic weight were used to analyze the expected genetic gain for individual character and combination of characters in order to construct selection indices by the package "plant breeding" of R-3.1.1 software according to the formula given by Singh and Chaudhary (1985).

The genotypic and phenotypic correlation coefficients were analyzed and presented in Table 1. no. of secondary branch, no. of female flower/plant, fresh weight/fruit (g), no. of male flower /plant, no. of primary branch, no. of fruit/plant had significant and positive correlation with yield per plant both at genotypic and phenotypic level. This analysis indicates that if these characters can be improve then the yield/plant will also improve. Similar observations was reported by Rao et al. (2000), Chowdhury and Sarma (2002) and Prasanna et al. (2002) in ridge gourd. Positive genotypic correlation of yield with fruits per plant was also in line with the results reported by Shah and Kale (2002).

On the other hand, peduncle length $(\mathrm{cm})$ and 100-seed weight $(\mathrm{g})$ represent strong negative correlation to yield both genotypic and moderate negative correlation phenotypic level. This indicates that improvement of this character would not be better for yield.

Path analysis was made to find out the direct and indirect effect of 14 traits on fruit yield per plant (Table 2). Path analysis revealed that number of fruits/plant and fresh weight/fruit (g) have direct effect on yield/plant (gm) in both genotypic and phenotypic level. So direct selection of plants based on these two traits would be effective to increase fruit yield or in other words overall yield. Length of main vine $(\mathrm{cm})$, number of male flower/plant, days to first male flowering represents positive direct effect on yield both genotypic and phenotypic level. These are the moderate contributing characters towards yield and selection based on these characters can be effective for developing high yielding ridge gourd varieties. Rao et al. (2000) found that path analysis revealed yield improvement could be achieved by direct selection for individual fruit weight of the vine in ridge gourd.

Number of seed/fruit represents direct negative direct effect on yield at both genotypic and phenotypic level. Thus, increase of yield per plant through direct selection for these traits should be avoided whereas indirect selection should be more appropriate to apply.

The characters showed that positive effect on yield had indirect positive effect via each other. Therefore, they do not affect each other adversely and hence can be selected for improving the yield. Path analysis revealed positive direct effect on fruit yield per plant through number of male flower/plant, number of female flower/plant and days to female flower/plant. Hence, these characters may be considered while making selection for improvement of ridge gourd.

In conventional breeding program improvement of crop based on many yield attributing characters is much complex, time consuming and laborious. Selection index is a well-established tool which signifies yield and other combination characters in precise form for quick, easy and economically favorable breeding program. Smith (1936) first suggested the use of the concept of a "discriminant function" as a logical and systematic manner of selecting plant lines to improve several quantitative characters simultaneously. Since that time, this method has become known as selection index. Different selection indices, their expected genetic advances with relative efficiencies are presented in Table 3.

Selection index is commonly used in grain crop for selecting efficient combination characters and improvement of crop based on that combination index. Selection index was reported by Yang et al. (1991) in wheat, Habib et al. (2007) in rice and Bashar et al. (2015) in egg plant.

It was observed that selection for individual character number of secondary branch had higher genetic gain (1.14) and relative efficiencies (294.70\%) over straight selection for yield. It was indicated that this trait was enough to determine the genotypic value of a genotype than yield and 


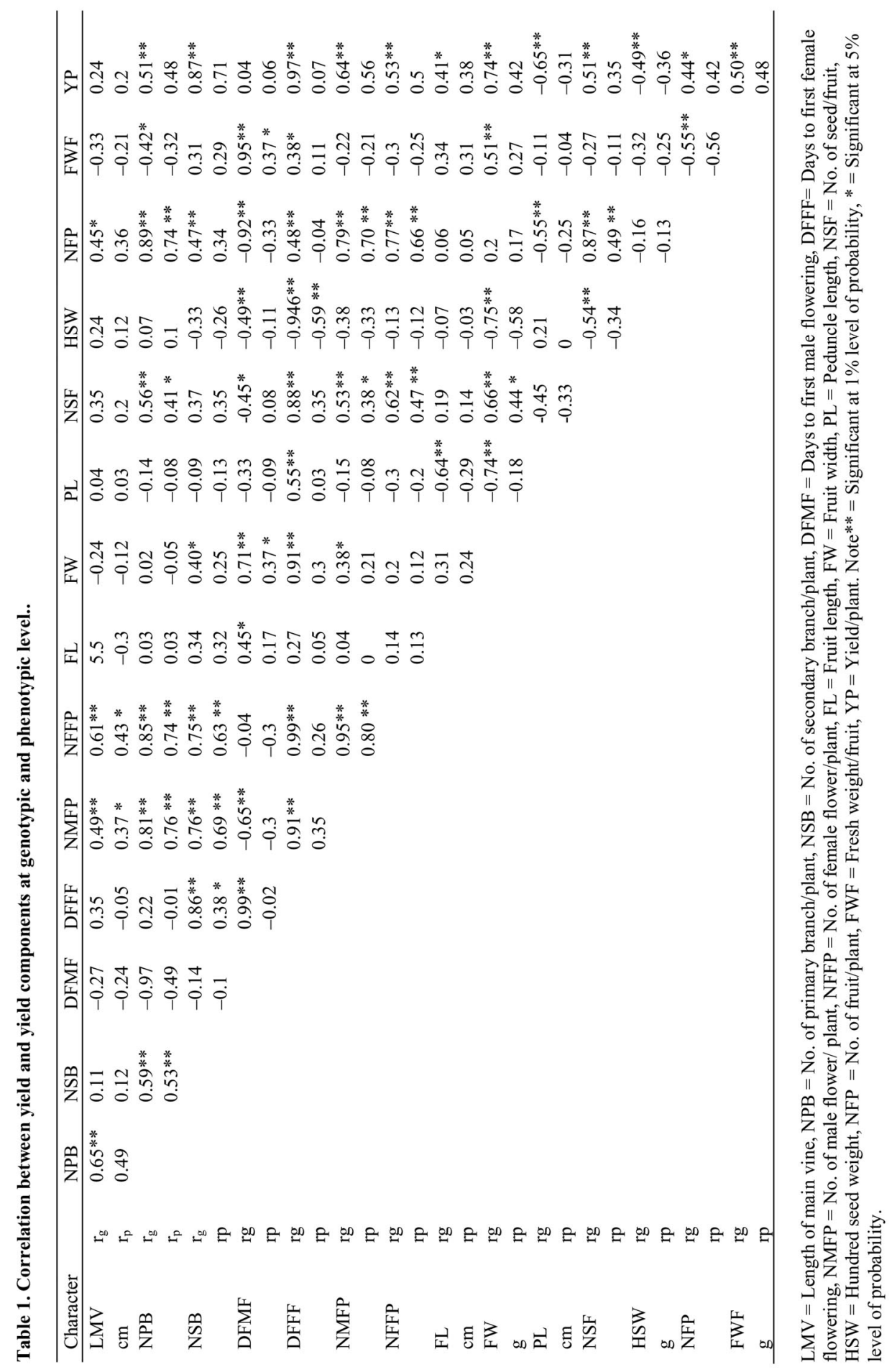




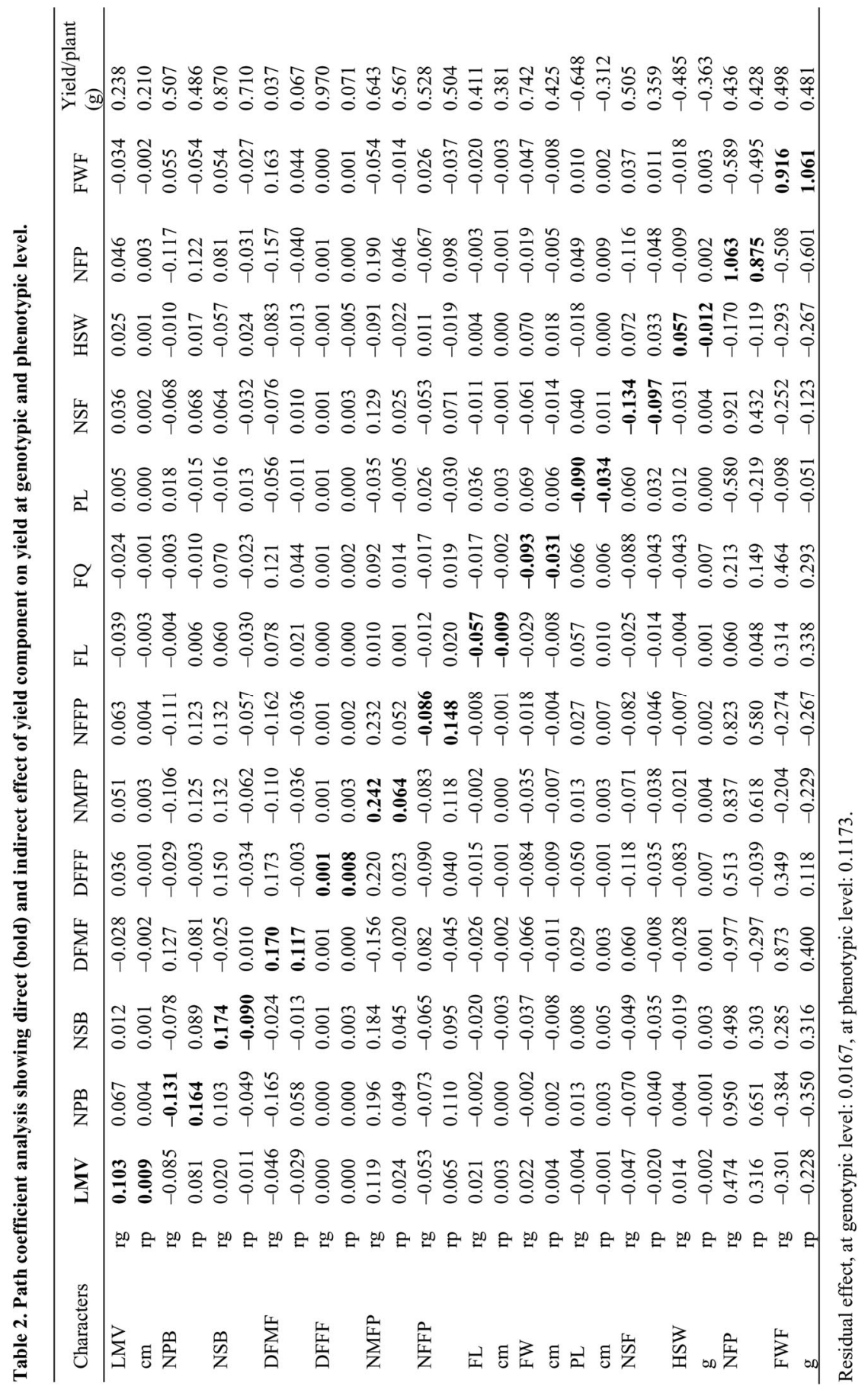


Table 3. Selection function, expected genetic advance (GA) and relative efficiency (RE\%) of different selection indices of ridge gourd.

\begin{tabular}{|c|c|c|}
\hline $\begin{array}{l}\text { Selection } \\
\text { function }\end{array}$ & $\begin{array}{l}\text { Expected genetic } \\
\text { gain }(\mathrm{GA})\end{array}$ & $\begin{array}{l}\text { Relative efficiency over } \\
\text { direct selection (RE \%) }\end{array}$ \\
\hline $\mathrm{I}_{1}=\mathrm{b} 1 \times 1$ & 0.39 & 100.00 \\
\hline $\mathrm{I}_{2}=\mathrm{b} 2 \times 2$ & 1.14 & 294.70 \\
\hline $\mathrm{I}_{3}=\mathrm{b} 3 \times 3$ & 0.76 & 195.79 \\
\hline $\mathrm{I}_{4}=\mathrm{b} 4 \times 4$ & 0.43 & 110.15 \\
\hline $\mathrm{I}_{5}=\mathrm{b} 5 \times 5$ & 0.52 & 133.43 \\
\hline $\mathrm{I}_{12}=\mathrm{b} 1 \times 1+\mathrm{b} 2 \times 2$ & 1.54 & 398.08 \\
\hline $\mathrm{I}_{13}=\mathrm{b} 1 \times 1+\mathrm{b} 3 \times 3$ & 1.07 & 277.14 \\
\hline $\mathrm{I}_{14}=\mathrm{b} 1 \times 1+\mathrm{b} 4 \times 4$ & 0.69 & 178.60 \\
\hline $\mathrm{I}_{15}=\mathrm{b} 1 \times 1+\mathrm{b} 5 \times 5$ & 0.79 & 203.87 \\
\hline $\mathrm{I}_{23}=\mathrm{b} 2 \times 2+\mathrm{b} 3 \times 3$ & 1.82 & 470.28 \\
\hline $\mathrm{I}_{24}=\mathrm{b} 2 \times 2+\mathrm{b} 4 \times 4$ & 1.45 & 375.40 \\
\hline $\mathrm{I}_{25}=\mathrm{b} 2 \times 2+\mathrm{b} 5 \times 5$ & 1.38 & 357.86 \\
\hline $\mathrm{I}_{34}=\mathrm{b} 3 \times 3+\mathrm{b} 4 \times 4$ & 1.15 & 297.76 \\
\hline $\mathrm{I}_{35}=\mathrm{b} 3 \times 3+\mathrm{b} 5 \times 5$ & 0.81 & 210.07 \\
\hline $\mathrm{I}_{45}=\mathrm{b} 4 \times 4+\mathrm{b} 5 \times 5$ & 0.46 & 118.34 \\
\hline $\mathrm{I}_{123}=\mathrm{b} 1 \times 1+\mathrm{b} 2 \times 2+\mathrm{b} 3 \times 3$ & 2.19 & 566.90 \\
\hline $\mathrm{I}_{124}=\mathrm{b} 1 \times 1+\mathrm{b} 2 \times 2+\mathrm{b} 4 \times 4$ & 1.83 & 472.04 \\
\hline $\mathrm{I}_{125}=\mathrm{b} 1 \times 1+\mathrm{b} 2 \times 2+\mathrm{b} 5 \times 5$ & 1.79 & 462.23 \\
\hline $\mathrm{I}_{134}=\mathrm{b} 1 \times 1+\mathrm{b} 3 \times 3+\mathrm{b} 4 \times 4$ & 1.44 & 371.41 \\
\hline $\mathrm{I}_{135}=\mathrm{b} 1 \times 1+\mathrm{b} 3 \times 3+\mathrm{b} 5 \times 5$ & 1.2 & 310.41 \\
\hline $\mathrm{I}_{145}=\mathrm{b} 1 \times 1+\mathrm{b} 4 \times 4+\mathrm{b} 5 \times 5$ & 0.85 & 219.04 \\
\hline $\mathrm{I}_{234}=\mathrm{b} 1 \times 1+\mathrm{b} 4 \times 4+\mathrm{b} 5 \times 5$ & 2.17 & 559.78 \\
\hline $\mathrm{I}_{235}=\mathrm{b} 2 \times 2+\mathrm{b} 3 \times 3+\mathrm{b} 5 \times 5$ & 1.93 & 500.25 \\
\hline $\mathrm{I}_{245}=\mathrm{b} 2 \times 2+\mathrm{b} 4 \times 4+\mathrm{b} 5 \times 5$ & 1.58 & 408.02 \\
\hline $\mathrm{I}_{345}=\mathrm{b} 3 \times 3+\mathrm{b} 4 \times 4+\mathrm{b} 5 \times 5$ & 1.08 & 279.78 \\
\hline $\mathrm{I}_{1234}=\mathrm{b} 1 \times 1+\mathrm{b} 2 \times 2+\mathrm{b} 3 \times 3+\mathrm{b} 4 \times 4$ & 2.52 & 651.35 \\
\hline $\mathrm{I}_{1235}=\mathrm{b} 1 \times 1+\mathrm{b} 2 \times 2+\mathrm{b} 3 \times 3+\mathrm{b} 5 \times 5$ & 2.34 & 603.74 \\
\hline $\mathrm{I}_{1245}=\mathrm{b} 1 \times 1+\mathrm{b} 2 \times 2+\mathrm{b} 4 \times 4+\mathrm{b} 5 \times 5$ & 1.98 & 512.23 \\
\hline $\mathrm{I}_{1345}=\mathrm{b} 1 \times 1+\mathrm{b} 3 \times 3+\mathrm{b} 4 \times 4+\mathrm{b} 5 \times 5$ & 1.46 & 377.20 \\
\hline $\mathrm{I}_{2345}=\mathrm{b} 2 \times 2+\mathrm{b} 3 \times 3+\mathrm{b} 4 \times 4+\mathrm{b} 5 \times 5$ & 2.21 & 571.53 \\
\hline $\mathrm{I}_{12345}=\mathrm{b} 1 \times 1+\mathrm{b} 2 \times 2+\mathrm{b} 3 \times 3+\mathrm{b} 4 \times 4+\mathrm{b} 5 \times 5$ & 2.6 & 672.09 \\
\hline
\end{tabular}

$\mathrm{I}_{1}=$ Yield/plant $(\mathrm{g}), \mathrm{I}_{2}=$ No. of secondary branch, $\mathrm{I}_{3}=$ No. of male flower/plant, $\mathrm{I}_{4}=$ No. of fruit/plant, $\mathrm{I}_{5}=$ Fresh weight/fruit. 


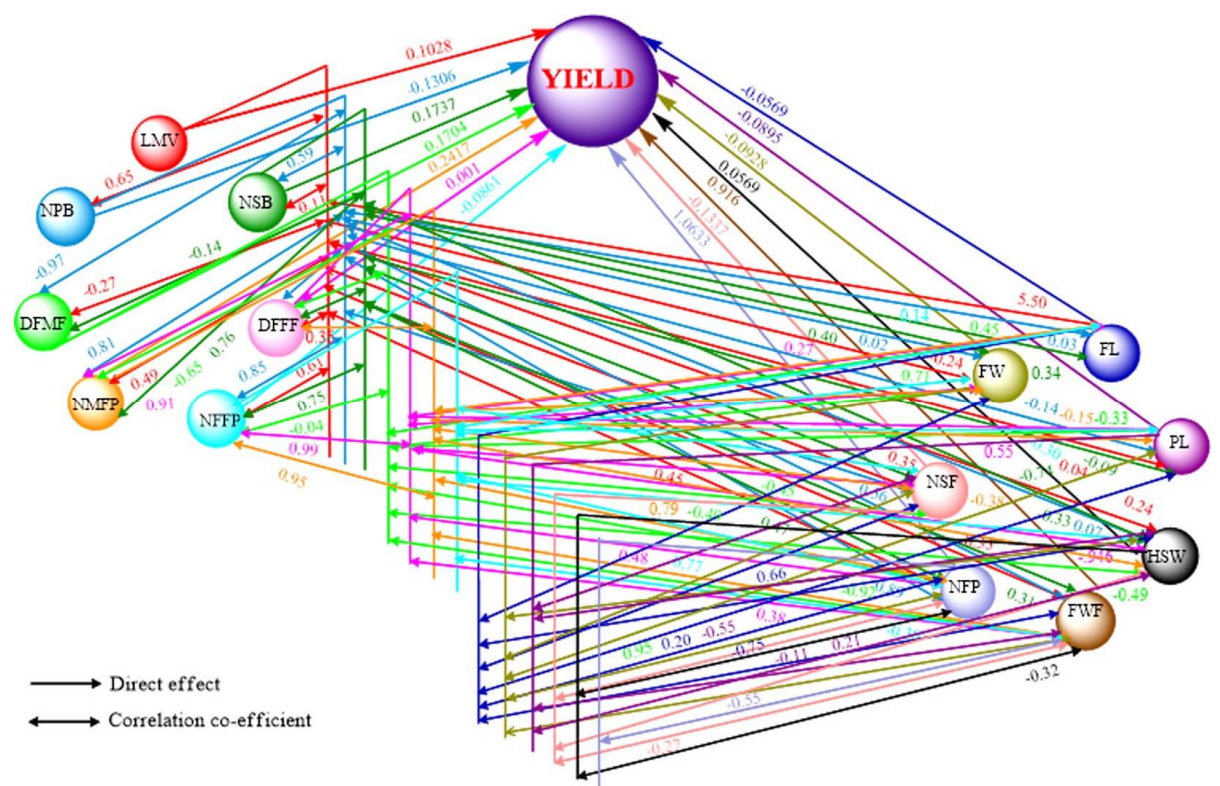

Fig. 1. Path diagram of different yield contributing characters on yield at genotypic level.

LMV = Length of main vine, NPB $=$ No. of primary branch/plant, NSB $=$ No. of secondary branch/plant, DFMF $=$ Days to first male flowering, DFFF $=$ Days to first female flowering, NMFP $=$ No. of male flower/plant, NFFP $=$ No. of female flower/plant, $\mathrm{FL}=$ Fruit length, FW $=$ Fruit width, $\mathrm{PL}=$ Peduncle length, NSF $=$ No. of seed/fruit, HSW $=$ Hundred seed weight, NFP $=$ No. of fruit/plant, FWF $=$ Fresh weight/fruit, YP $=$ Yield $/$ plant.

other characters. Relative efficiencies of yield/plant (g) was $100.00 \%$, number of male flower/plant was $195.79 \%$, number of fruit/plant was $110.15 \%$ and fresh weight/fruit was $133.43 \%$. When two characters were included in selection index higher genetic gain (1.82) and relative efficiency $470.28 \%$ was obtained for $\mathrm{I}_{23}$ (number of secondary branch + no. of male flower/plant) followed by $398.08 \% \mathrm{I}_{12}$ (yield/plant $(\mathrm{g})+$ number of secondary branch). Then three characters were included in the selection index, maximum genetic gain (2.19) and relative efficiency $(566.90 \%)$ over selection for yield was obtained for the index $\mathrm{I}_{123}$ based on yield/plant (g) + number of secondary branch + no. of male flower/plant characters. In the presented functions, selection indices $\mathrm{I}_{1234}$ and $\mathrm{I}_{12345}$ showed highest relative efficiency over direct selection and genetic gain when all the characters were included to construct the selection index. Similar observation was made by Bashar et al. (2015) in eggplant.

Finally, it may be concluded that the index $I_{123}$ based on three characters yield/plant (g), number of secondary branch, number of male flower/plant showing genetic gain (2.19) and relative efficiency $(566.90 \%)$ are comparable to those indices based on four or more characters which are desirable in improvement program.

\section{References}

Altinisik A, Gur E and Oldas S 2010. A natural sorbent Luffa cylindrica for the removal of a modal basic dye. J. Hazard. Mater. 179(1-3): 658-664.

Bashar A, Hasan R, Alam, N, Hossain MK, Nguyen Vu, Hong AN and Mahmudul Huque AKM 2015. Assessment of trait efficiency and selection of parents in brinjal (Solanum melongena L.), Plant Gene and Trait 6(7): 1-18.

BBS 2018. Bangladesh Bureau of Statistics. Statistical Yearbook of Bangladesh. 30th edn, Dhaka. p. 207. 
Chowdhury D and Sarma KC 2002. Studies on variability, heritability, genetic advance and correlations in ridge gourd (Luffa acutangula L.). Hort. J. 15(3): 53-58.

Gopalan C, Sastri VR, Balasubramanium SC, Rao BSN, Dosthale YG and Pant KC 1999. Nutritive value of Indian foods. Indian Council of Medical Research Technological Bulletin. National Institute of Nutrition, Hyderabad, India.

Habib SH, Iftekharuddaula KM, Bashar MK, Akter K, and Hossain MK 2007. Genetic variation, correlation and selection indices in advanced breeding lines of rice (Oryza sativa L.). Bangladesh Journal of Plant Breeding and Genetics 20(1): 25-32.

Lee S and Yoo JG 2006. Method for preparing transformed Luffa cylindrica Roem. World Intellectual Property Organization.

Prasanna SC, Krishnappa KS and Reddy NS 2002. Correlation and path coefficient analysis studies in ridge gourd. Agril. Sci. 31(9/10): 150-152.

Rao BN, Rao PV and Reddy BMM 2000. Correlation and path analysis in the segregating population of ridge gourd (Luffa acutangula L.). Crop Res. Hisar. 20(2): 338-342.

Shah SR and Kale PN 2002. Yield component association analysis in ridge gourd. J. Maharashtra Agril. Univ. 27(2): 197-198.

Shekhavat AKS, Singh B, Yadav JR and Srivastava J P 2005. Character association in okra (Abelomochus esculentus Monech). Plant Archies 5: 289-291.

Singh R K, and Chaudhary B D, 1985, Biometrical methods in quantitative genetic analysis, Third Edition, Kalyani Publishers, New Delhi, India, pp. 287-293.

Smith HF 1936. A discriminant function for plant selection. Ann. Eng. 7: 240-250.

Yang ZP, Wu ZS and Lin YB 1991. Inheritance and selection of agronomic characters in an intermating population of wheat. Acta Agricultarae Shanghai 7(1): 23-28.

(Manuscript received on 16 February, 2019; revised on 15 April, 2020) 